\title{
引張りおよび圧縮の初期残留応力領域での 疲学裂進展についで
}

\author{
本田和 男** 鳥居太始之** \\ 三宅雄二郎*** 坂 本 達 治****
}

\section{Fatigue Crack Propagation in the Region having Tensile or Compressive Residual Stress}

by

\author{
Kazuo Honda, Tashiyuki ToRII, Yujiro MiYake \\ (Faculty of Engineering, Okayama University, Okayama) \\ and Tatsuji Sakamoto \\ (Nissan Motor Co. Ltd., Yokohama)
}

\begin{abstract}
The laminated inhomogeneity and the residual stress are important factors controlling the fatigue strength of the surface hardened metals.

In this report, the fatigue crack propagation of the sheet specimens which have tensile or compressive uniaxial residual stress but no laminated inhomogeneity was discussed. The main results obtained are as follows ;

The fatigue crack propagation rate increased in the region of tensile residual stress but decreased in the region of compressive residual stress at the condition of the stage II b of the fatigue crack propagation mechanism, where the striations are predominant on the fractured surface. It seems that the effect of the initial compressive residual stress on the fatigue crack propagation does not always follow the above result, and it is closely related to the fatigue crack propagation mechanism.

キー・ワード : 引張残留応力, 圧縮残留応力, 疲労き裂進展速度, 疲労き裂進展機構

(Received Mar. 15, 1980)
\end{abstract}

\section{1 緒言}

高周波焼入材，表面塑性加工材，浸炭・窒化材など の表面硬化材が害用部材として多く使用されれ，その疲 労強度に関する研究が多数報告されている. その疲労 強度を上昇させる要因としては, 表面層に生ずる材質 変化抏よび厌縮残留応力が基本的な因子であると述べ られている。しかしながら，実際にはその両因子を分 離して定量的に変光得る適当な実験手段がなく, 両因 子が疲労破壊に及淁す定説に関しては必ずしも充分で あるとは言えない現状である。

そこで，著者らは，まず前述の両因子を分離する実 験手法を確立することが重要であると考兄，中炭素鋼

\footnotetext{
* 本報を「初期残留応力と疲労き裂進展挙動（第 1 報）「Init1al Residual Stress and Fatigue Crack Propagation, I」とす る.

原稿受理 昭和55年 3 月 15 日

** 正会 員 岡山大学工学部 岡山市建島中

*** 学生会員 岡山大学大学院 岡山市律島中

***** 日産自動車(株) 横浜市鶴見区大黒町
}

・低炭素鋼クラッド材を用いて，不均質層が接合され たままの状態で初期残留応力を定量的に変光得ること の検討执よびその疲労試験を行ってきだ. しかし，一 般の不均質性であるがゆ学に生ずる場合と同様に，純 粋に初期残留応力だけの効果を直接取り出せる試料と なって扔らず，初期残留応力を問題にする場合不均質 性の効果を併せて検討する必要があった。すなわち， 初期残留応力と疲労破壤との関連を調べるための試験 片としては，不均質性のないことが必要と思われる。 さらに, 著者らは, 疲労き裂の進展挙動を非破壊的に 測定された残留応力分布との関連で検討できるょらに 薄板材であること，および負荷応力との対応では初期 残留応力ができるだけ一軸状態に近いことなどを満足 する試験片が必要であろうと考皃た。

ここでは，上述の条件を満足する試験片を得るため の熱応力を用いた製作方法を述べるとともに，試験片 の光学顕微鏡組織, 硬さ分布抒よび残留応力分布を調 ベた．さらに，その試験片を用い，初期残留応力が疲 
労破壊に及ぽす影響の基本的な考え方を得るための第 1段階として, 引張り执よび圧縮といら符号の異る初 期残留応力領域での疲労き裂進展挙動がどのようにな っているかについて，主として実験的な立場で検討を 加完た。

\section{2 軸方向残留応力をもつ均質薄板材製作の考え方} 一般に，炭素鋼焼入材に生ずる残留応力の発生は， 急冷に伴ら試料内温度こう配によって, 熱応力と変態 応力が生ずることが原因であると考えられている.こ のことは, 暁入温度を $A_{1}$ 変態点以下に選ぶと, 変態 組織はほとんど現れず熱応力型残留応力のみを生じる ことを示している.しかし，このような残留応力発生 の考方はブロック状の試料形状についてなされたも のであり, 試料板厚方向の冷却が瞬間的に起る薄板材 では, 板幅内温度こう配が著しくないため, その熱応 力型残留応力は生じにくくなると考えられる．そこで， 薄板材幅方向に分布する残留応力を発生させる方法を 次のように考えた。

Fig. 1 に示すように, 中央にある薄板試験片の両側 から試験片と同材質 - 同形状で板厚の充分大きい治具 で保持し，さらに加熱・冷却時に試験片とこれらの治 具が離れないよらにするため, 押え板によりボルトで 両側から締め付けて一体化する. この状態で変態を起 さない $A_{1}$ 変態点以下の温度から焼入れを行う. 焼入 れ後ボルトを外し治具から開放すれば, 試験片は薄板 でかつ板幅に対する試験片長さは充分大さいため軸方 向応力が支配的となりまたそれは熱応力型であるた め両側圧縮 - 中央部引張りの残留応力分布となる試験 片が得られると考兄られる. 一方, 暁入れに伴うマル テンサイト変態は生じないため, 硬さ分布に現れるよ らな試料内部の材質変化はなく全体的には均質である と考えてよいと思われる.さらに，この方法によれば， $A_{1}$ 変態点以下の焼入温度和よび泠却剂を適当に選ぶ

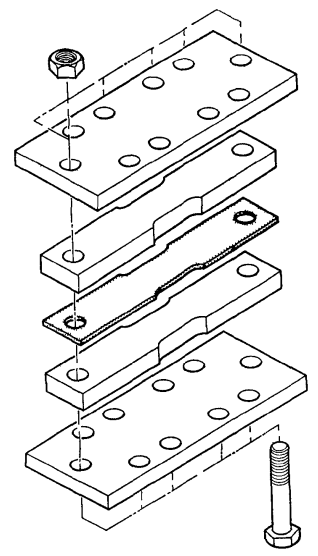

Fig. 1. Jig for producing the uniaxial residual stress.
ことにより燒入れ時の試料内温度こう配が種々变化す るので, 残留応力の大きさを定量的に変えることがで きると考觉られる。

\section{3 実 験 方 法}

\section{$3 \cdot 1$ 試験片}

使用した材料は S45C 材で，その化学成分を Table I に示す. 試験片は, Fig. 2 に示す形状寸法で切欠き 半径 $1.5 \mathrm{~mm}$ の中央穴切欠き材(a)和よび両側半円切欠 き材(b)である. 機械加工後エメり一紙で表面およざ穴 縁を仕上げ，加工等の影響を除くため $900{ }^{\circ} \mathrm{C} ， 1$ 時間 保持の真空焼なをしを行った. 引き続いて，前項で述 ベた方法に基づいて軸方向残留応力を発生させるため の熱処理を行った. すなわち, 残留応力の絶対值があ る程度大さくなるように, 冷却剤を水として, 焼入れ 温度は $700^{\circ} \mathrm{C}, 600^{\circ} \mathrm{C}$ 抢よび $500^{\circ} \mathrm{C}$ の 3 種類でそれどれ の異る大きさの残留応力值が得られるようにした。

Table I. Chemical composition (\%).

\begin{tabular}{c|c|c|c|c|c}
\hline & $\mathrm{C}$ & $\mathrm{Si}$ & $\mathrm{Mn}$ & $\mathrm{P}$ & $\mathrm{S}$ \\
\hline $\mathrm{S} 45 \mathrm{C}$ & 047 & 022 & 0.70 & 0.015 & 0.019 \\
\hline
\end{tabular}

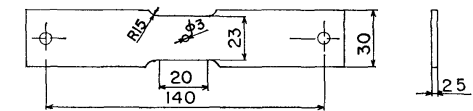

(a) For crack propagation of tensile residual stress

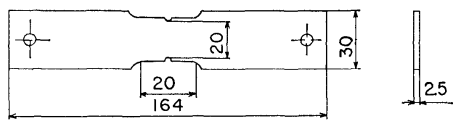

(b) For crack propagation of compressive residual stress

Fig. 2. Dimension of specimens.

\section{$3 \cdot 2$ 硬さ分布および残留応力分布の測定}

硬さ分布の測定はマイクロビッカース硬度計を用い て行われた．測定値は長手方向と平行な線に沿い3〜 5 点の平均値である。

残留応力の測定は試験片表面を軽く電解研摩した後, 東芝製X線応力測定装置を用いて行われた。な执，照 射面積は $2 \times 1 \mathrm{~mm}^{2}$ で，その他の条件は $\mathrm{Cr}-\mathrm{K} \alpha$ 回折 線を用いた通常のX線応力測定条件とほぼ同様である. 長手方向扣よび幅方向残留応力の分布は, 試験片を幅 方向に移動して測定された. 回折強度曲線のピーク位 置の決定には半価幅法を採用し, 最小二乗法により, $\sin ^{2} \psi-2 \theta$ 線図のこう配を求めた.

\section{$3 \cdot 3$ 疲労試験}

疲労試験は島津製サーボパルサーを用いて, 繰返し 速度 $20 \mathrm{~Hz}$ の完全両振りの引張圧縮正弦波形で定荷重 振幅の条件で行った，疲労き裂長さは，適時繰返した 後試験機に備兄つけた倍率 100 倍の光学顕微鏡にて測 定した。な括，疲労き裂進展曲線に括けるき裂長さと 
しては，両側のき裂長さを平均して求めた。ただし， 両側で著しく差のある場合は除外した。

\section{$3 \cdot 4$ き裂および破面の観察}

き裂の観察は光学顕微鏡にて撮影した写真を用いて 行った。また, 疲労破面の観察は明石製作所製走查電 子顕微鏡ミニ・セム MSM-9 を用いて行われた.

\section{4 実験結果および考察}

$4 \cdot 1$ 試験片の残留応力分布, 硬さ分布および組織 Fig. 3 は試験片の残留応力分布測定結果である.す なわち, 軸方向に拈いて両側圧縮・中央部引張りの熱 応力型残留応力分布となり，その大きさも両側半円切 欠き拉よび中央円切欠きに执いてほとんど差のないこ とが $700^{\circ} \mathrm{C}$ 焼入材においてわかる. しかし，焼入温度 によってその分布は異り, その絶対值は $700{ }^{\circ} \mathrm{C}$ にい て最も大きく, $600{ }^{\circ} \mathrm{C}$ 打よ゙ $500^{\circ} \mathrm{C}$ の順に減少している.

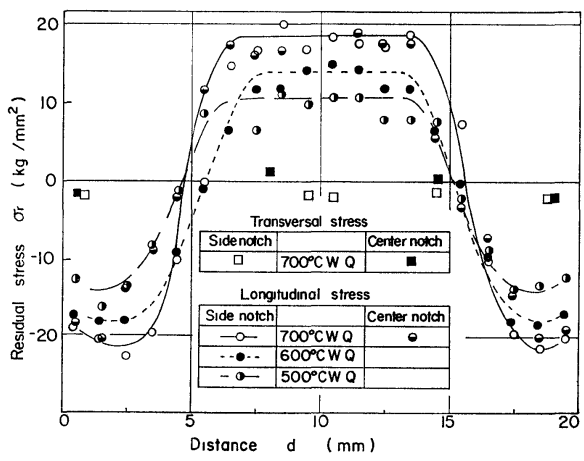

Fig. 3. Distribution of initial residual stress.

また，幅方向残留応力は $700{ }^{\circ} \mathrm{C}$ の場合について示すが， 両側切欠き㧊よび中央切欠きに执いてほとんどないこ ともわかる. このような薄板試験片の残留応力測定結 果から，両側切欠さ材および中央切欠き材を用いれば 圧縮および引張りの初期残留応力領域に分けて疲労き 裂進展挙動を検討するための試験片として好都合なこ と, しかもその残留応力は軸方向に扔いて支配的であ ることがわかる.

つぎに，上述のような残留応力分布に対応して，そ れぞれの試験片の硬さ分布を Fig. 4 に示す.これよ り, いずれも試験片内の硬さはほぼ一定であり, 各試 験片による差はほとんどないことがわかる. また，光

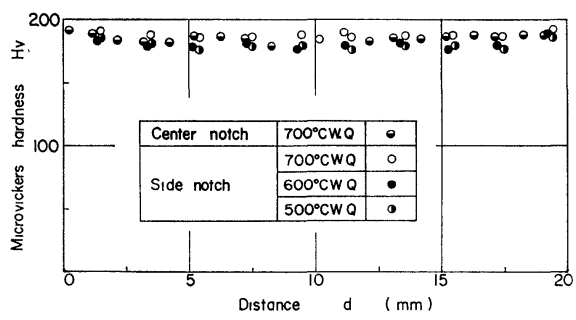

Fig. 4. Distribution of hardness.
学顕微鏡による組織観察を行ったが，各試験片の間で 扣よび同一試験片の異る場所で，識別できるほどの顕 著な差はみられなかった。このように，それぞれ異る 残留応力をもつ各試験片に沶いて，材質的にはほぼ同 一であるとみなしてよいと思われる。

\section{$4 \cdot 2$ 疲労き裂進展曲線とその整理}

Fig, 5 は, $700^{\circ} \mathrm{C}$ 水焼入材の初期引張残留応力領域 から発生した疲労き裂進展曲線である.これより，疲 労き裂進展に伴いその速度は著しく大きくなり，初期 残留応力の減少に対応してき裂進展速度の減少は起ら ず，逆に増大して最終破断に至っていることがわかる。 すなわち,このような場合の初期圧縮残留応力は, き 裂長さが長くて最終破断期に入った場合は疲労き裂進 展を抑制する効果がないことがわかる.

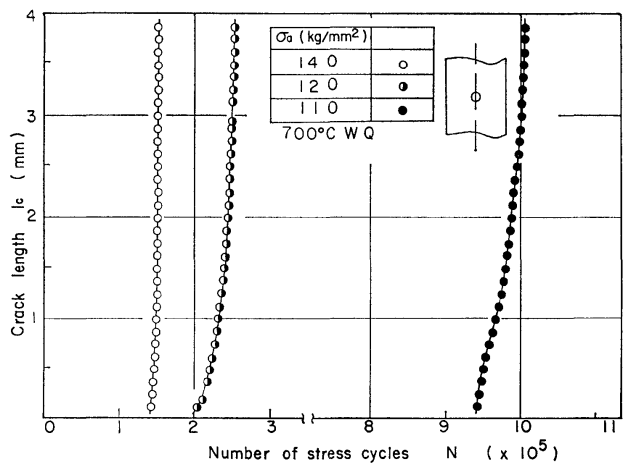

Fig. 5. Crack propagation curve (for tensile residual stress).

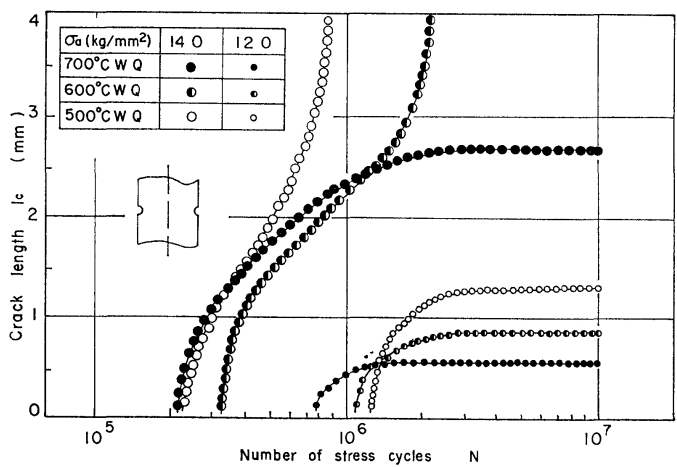

Fig. 6. Crack propagation curve (for compressive residual stress).

一方, Fig. 6 は $700^{\circ} \mathrm{C}, 600^{\circ} \mathrm{C}$ 牤よび $500^{\circ} \mathrm{C}$ の水焼入 材でそれぞれ大ささを変えた初期圧縮残留応力中から 発生した疲労き裂の進展曲線である.なお，横軸は対 数目盛で示した. その進展曲線は Fig. 5 の初期引張 残留応力の結果とは著しく異り, 初期進展後急激に減 少する進展速度となりき裂は停留する場合がある。す なわち, 応力振幅 $\sigma_{a}=14 \mathrm{~kg} / \mathrm{mm}^{2}$ に拈いては最も初 期圧縮残留応力の大きい $700{ }^{\circ} \mathrm{C}$ 水焼入材で停留き裂と 
なり， $\sigma_{a}=12 \mathrm{~kg} / \mathrm{mm}^{2}$ 火小いては初期圧縮残留応力 值の大きいほど短い長さでき裂が停留しているのがわ かる.このよらな疲労き裂進展明線になるという意味 に括いて, 初期圧縮残留応力中加瘦労裂加発生寸 る場合の疲労強度あるいは疲労寿命が増大すると考光 てよいものと思われる。

つぎに，Fig.7 は Fig.6 の結果からき裂進展速度 とき裂長さとの関係を整理したものである。これより， 初期進展域のき裂進展速度は, 応力振幅の大きさには 低存するが初期圧縮残留応力の大きさにはほとえど関 係しないことがわかる。步なわち, 進展初期の速度は 初期压縮残留忘力が大きいからと言って，小さくなる とは限らないことを示している. 一方, き裂長さが大 さくなると初期圧絠残留応力の大きさはき裂進展速度 を減少させる效果のあることがわかる。

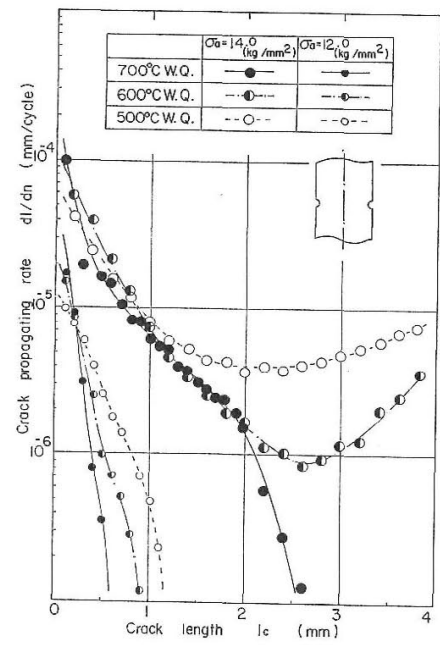

Fig. 7. The relationship between crack propagation rate and crack length.

Fig. 8 はある定の疲労き裂長さ $l_{c}$ に達するまで の庍力繰迡し数と応力振幅との関係について，700 $\mathrm{C}$ 水尭入材で得られた引張り和よび圧縮の初期残留応力 の效果を調べたものである。ただし，Fig.6 の結果に 他の応力振幅で得られた結果も加えてある。これより， 引張り特よび压縮といら初期残留応力の相違による效 果はき裂長さが短くなるにつれて小さくなり， $l_{c}=0.2$

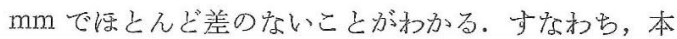
試験片のような切欠き材では，切欠き底板厚中央付近 で発生した疲労き裂が半だ円状に進展するものと思わ れるが，その痩学き裂発生繰返し数は初期残留広力の 符号によって医とんど関係しないるのと推測してよい と思われる。一方，西谷らは70/30黄銅を用い，片振 り引張り和よび片振り压縮となるよう平均応力を変化 させた場合， 1 ～結晶粒程度の大ささの疲労き裂発 生には両者に拈いて差のないことを報告している。こ

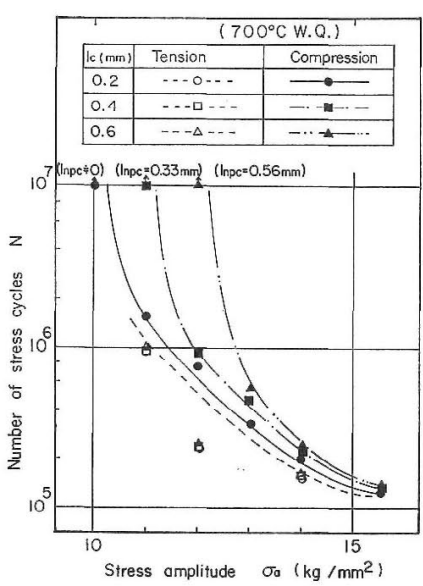

Fig. 8. Fatigue life to the constant crack length and stress amplitude.

のことと対応させて考光れば，初期残留応力も平均応 力と同等の效果があると考光てよい上らである。すな わち，さ裂発生さでの疲学被害は，すべり面に作用す る垂直応力には無関係であると，本実験結果に栋いて も考えればよいものと思われる。

\section{$4 \cdot 3$ 疲労き裂の観察}

切欠き底付近の初期進展域表面き裂が，引張り括よ び瓜縮の初期残留応力によってどのように相違するか について，700豆水焼入材を用いて調べた。すなわち， 引張残留応力領域では除荷時でもき裂は大きく開口し ており，前項で述べた急激なき裂進展速度の増大と対 応していた。一方, 压縮残留応力領域では周辺に多く の塑性変形域圭もつ不明りょらなき裂となり, 引張残 留応力領域のき裂の様相とは著しく相違していた。 そ こで,このような表面き裂に対し，き裂進展経路を明 確にすることは, 初期圧縮残留応力中での初期進展機

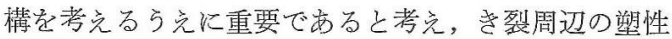
変形が少い試験片内面でのさ裂を観察するため側面よ り $0.8 \mathrm{~mm}$ 学エメリー紙物よびバフで研摩後ナイタル 液で軽く腐食した。そのき裂写真の一例をFig.9 亿

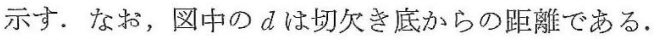
これより, き裂経路は, 生体としては荷重方向に直角 であるが枝分かれしたき裂が多く，なた局部的にはう

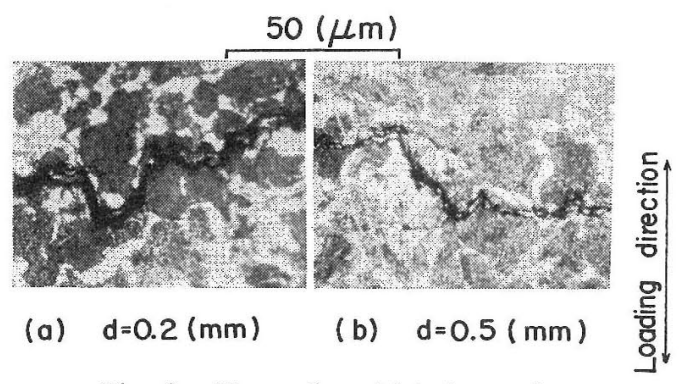

Fig. 9. Observation of interior cracks. 


\section{Width direction of specimen}

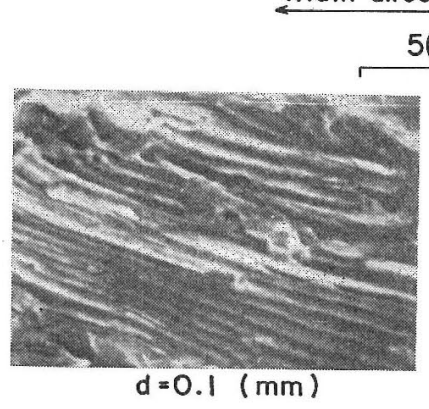

(a) Tensile residual stress $5(\mu \mathrm{m})$

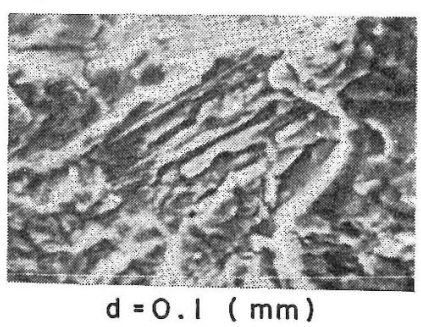

(b) Compressive residual stress

Fig. 10. Scanning electron micrographs.

余曲折しているのがわかる。しか子，年のら余曲折は 結晶粒界に沿っている箇所が多い上うに見受けられる。 なお，Fig. 9 は $\sigma_{a}=14 \mathrm{~kg} / \mathrm{mm}^{2}$ の結果で荡るが， $\sigma_{a}$ $=12 \mathrm{~kg} / \mathrm{mm}^{2}$ の初期進展域においても同様であった。

一方, 裂が進展して進展速度が段多減少している き裂は，内部観察において粒内を横切る細い直線状と

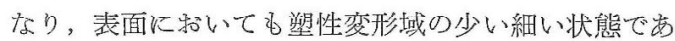
った.

\section{$4 \cdot 4$ 疲労破面の観察}

引張り拉上び圧縮の初期残留応力中を進展した疲労 き裂破面観察の一例として $\sigma_{a}=12 \mathrm{~kg} / \mathrm{mm}^{2}$ の場合を

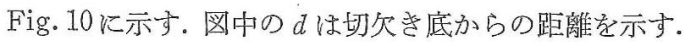
引張残留応力中のき裂破面では $d=0.1 \mathrm{~mm}$ ですでに ストライエーション模様となり, 進展初期からすでに 引張型さ裂進展機構が支配的で每ることがわかる。さ らに, $d=0.5 \mathrm{~mm}$ でも間隔のやや大常い同様の模様と なっていた，一方，压縮栈留応力中では， $d=0.1 \mathrm{~mm}$ で明りょうなストライエーションはなく凹円のある結 晶学的と思和机る破面起呈しているが，き裂が停留す る直前の $d=0.5 \mathrm{~mm}$ で完全なストライエーション模 栐であった。すなおち, 压縮残留応力中では, 准展初 期と学の後の進展と飞和いてき裂進展機構は異り, 初 期圧縮残留応力のき裂進展に及洔守与む区別して検 討する必要が西ると考党られる。な拉， $\sigma_{a}=14 \mathrm{~kg} /$ $\mathrm{mm}^{2}$ の破面では押しつぶされた形跡が多く岕り多少 不明りょうであったが，Fig. 10 の結果と活ぼ同様で 蚂った。

一方，大塚らは軟鋼焼ななし材の片振り圧縮疲觉試 験炕呿いても円穴縁上り $1 \mathrm{~mm}$ 程度の裂進展が生 ずること，括よびその瘦労破面に招いては粒界破面が 顕著にみられたことを報告している。すなおち，その 比較加ら初期压縮残留応力子压縮平均応力之同様な 効果をむたらするのと考党てよいと思わ机る。また， 粒界破面の発生に関しては, 応力拡大係数幅 $\Delta K$ 上り 最大応力拡大係数 $K_{\max }$ に依存することを指摘した
Ritchie の報告影上び平均応力の影響がかなりみられ ること走した大塚らの報告がある。粒界破面の生ず る理由については，な和不明な点为多いが，少くと承 $\Delta K$ 以外の要因汃関係していると考克てよいと思われ る。 そして, 初期圧縮残留応力は, 初期進展域に招い てそのような要因と密接に関係して，劣る程度のき裂 進展速度をるたらするのと考兄られる。たと光ば，粒 内破面率の最大值は, 要る特定の疲労学裂進展速度範 囲で現れることが報告されている。

\section{$4 \cdot 5$ 初期圧縮残留応力と停留き裂}

圧縮残留応力領域切欠き底で発生したき裂が初期進 展域を過ぎれば，き裂は第 $2 \mathrm{~b}$ 段階として進展すると してよいことが破面観察からわかった。㘯の段階での 疲労き裂進展速度 $d l / d n$ は $\Delta K$ 々密接に関係すること は周知のことである。したがって，進展速度が急隇し 华るき裂長さで停留さ裂となる現象に刘しては，実際 の $\Delta K$ に及ぼす初期圧縮残留応力の效果があると推測 される。

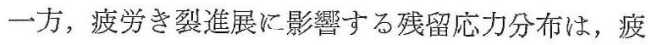
労過程での残留応力变化があるとすれば。初期残留応 力分布とは相違すると考它られる。そこで， $\sigma_{a}=12$ $\mathrm{kg} / \mathrm{mm}^{2}$ の場合について調べた。その結果をFig. 11 に示す。これより，切欠き底にすべり線が観察された 時点 $\left(N=0.7 \times 10^{6}\right)$ とほぼ停留さ裂になった時点 $\left(l_{e}\right.$

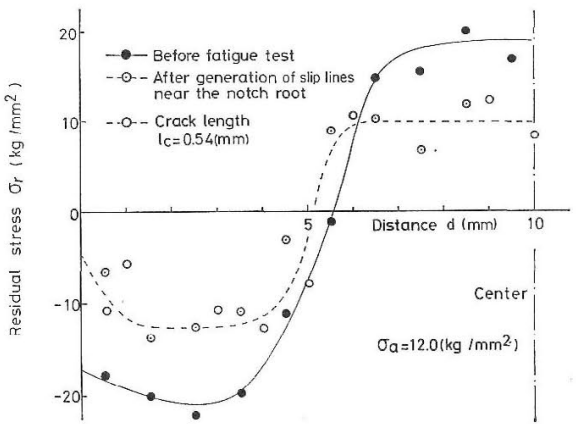

Fig. 11. Change of residual stress in fatigue. 
$=0.54 \mathrm{~mm}$ ）で残留応力分布はほぼ等しく，その分布 は初期残留応力に比較すればかなり減衰していること がわかる.すなわち, 圧縮残留応力中での短い長さの き裂進展に伴ら残留応力変化はほとんどないが, 応力 繰返しによる残留応力の減衰が生じ, とくに切欠き底 で顕著に生じていることがわかる.

以上のことから, 疲労き裂進展に対しては減衰後の 残留応力分布 $\sigma_{r}(x)$ を考光，これに負荷による切欠 き底付近の応力分布 $\sigma_{y}(x)$ を加えた值が最大引張負 荷時の切欠き底付近の応力分布となる.したがって, 切欠き底付近の短い長さ $l$ （切欠き半径 $\rho_{0}$ より小さ (範囲）のき裂に対する応力拡大係数 $K_{1}$ は次式で計 算できると考えられる.

$$
K_{1}=1.12\left\{\sigma_{y}(l)+\sigma_{r}(l)\right\} \cdot \sqrt{\pi l}
$$

なお，両振り疲労試験では $\Delta K=K_{1}$ として考光てよい と思われる.ささて，(1)式に有限要素法を用いて弾性計 算した $\sigma_{y}(l)$ と Fig. 11 減衰後の $\sigma_{r}(l)$ を代入して 計算した結果を, 疲労き裂進展速度と対応させて示し たのが Fig. 12 である.これより，第 $2 \mathrm{~b}$ 段階に対応 する初期進展後のき裂進展域では, き裂長さの増大に つれて減少する $\Delta K$ に対応して $d l / d n$ も減少すること がわかる.そして， $\Delta K$ が下限界值 $(\Delta K)_{t h}$ になれば 停留き裂になると考光てよいと思われる.

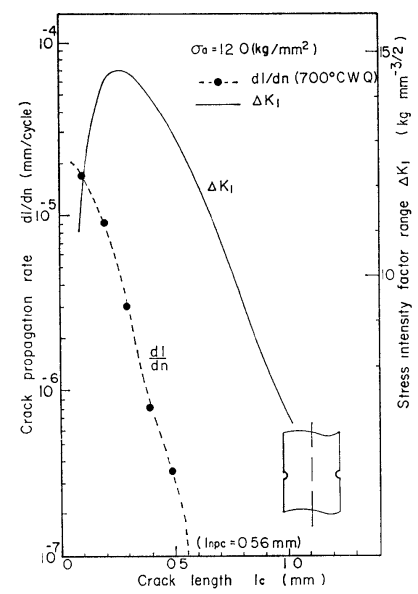

Fig. 12. The comparison of crack propagation rate with stress intensity factor.

\section{5 結言}

本報告で述べた方法で焼入れを行らことにより，ほ とんど材質変化を伴わない状態で，絶対值の比較的大 きい引張りおよび王縮の軸方向残留応力が支配的であ る薄板試験片を製作することがでさた，その試験片を
用いて次の結果を得た.

（1）側面のごく短いき裂長さに達するまでの応力繰 返し数に対しては, 引張りおよび瓦縮という初期残留 応力の符号による相違はほとんどない.

（2）同じ初期残留応力分布に対して, 引張り残留応 力領域から疲労き裂発生・進展する疲労寿命は圧縮残 留応力からのそれに比べて著しく小さい。これは, 疲 労き裂進展に対する初期残留応力の効果が大きいため である。

（3）引張りおよび圧縮の初期残留応力が疲労き裂進 展速度をそれぞれ増大打よび減少させる効果は, 第 2 $\mathrm{b}$ 段階の疲労き裂進展に括いてである.すなわち, 初 期圧縮残留応力が疲労き裂進展に及ぼす寄与は, 必ず しもこのよらな結果になるとは限らず, それは疲労き 裂進展機構との関係が重要であった。

おわりに，有益なご助言をいただきました九州大学 の西谷弘信教授，および貴重なご忠告をいただきまし た大阪大学の大路清嗣教授に謝意を表します。また， 実験装置製作に協力された技官德田勝氏に感謝します. （昭和54年11月 7 日 第13回疲労シンポシウムにて講演）

\section{参 考文 献}

1）中村 宏，“高周波焼入と疲労強度”, p. 63 (1963) 日刊 工業新聞社

2）光永公一, 福武 諄, 日本機械学会論文集， 39,42 (1973).

3）早山 徹, 日本機械学会論文集, 41, 721 (1975).

4）本田和男，鳥居太始之，山谷純史，材料， 26, 551 (1977).

5) 本田和男, 鳥居太始之, 宮本俊郎, 日本機械学会論文集, 45, 108 (1979).

6）荒木 透編集，“鋼の熱処理技術”, p.215 (1969) 朝倉 書店

7) 大塚昭夫, 森 要, 第22回材料強度と破壊国内シンポ ジウム論文集, 1 (1977).

8）西谷弘信, 山下尚義, 日本機械学会論文集, 32, 1456 (1966).

9) Ritchie, R. O., Engng. Fract. Mech., 7, 187 (1975).

10）村上理一, 小林英男, 小峰厚友, 中沢 一, 日本機械学 会論文集, 43, 799 (1977).

11）大塚昭夫, 森 要, 日本機械学会論文集, 45, 1312 (1979).

12）西谷弘信, 石田 誠, 日本機械学会論文集， 39,7 (1973). 